\title{
Parathyroid carcinoma with sarcomatoid differentiation: a case report and literature review
}

\author{
Liang Hu and Xiaojun Xie ${ }^{*}$ (D)
}

\begin{abstract}
Background: Parathyroid carcinoma (PC) is a rare thyroid tumor. PC with sarcomatoid differentiation(PCSD) is even rarer and its exact etiology remains unclear. We here report a case of PCSD, and present the clinicopathological features and pathological diagnosis and review the literature.

Case presentation: A 71-year-old man presented with a mass of $4.5 \mathrm{~cm} \times 3.5 \mathrm{~cm}$ in the right neck. The tumor was composed of nest-like transparent cells, and the septum had heterotypic rhabdoid cells with sarcomatoid differentiation. Immunophenotype was as follows: myogenic differentiation 1(MyoD1), myogenin and desmin were positive; clear cells were positive for chromogranin A(CGA), synaptophysin(Syn) and GATA-3; and Ki-67 proliferation index was $40 \%$. Hematoxylin and eosin staining and immunohistochemistry were performed. The patient was diagnosed with PCSD, and died 6 months after surgery.

Conclusions: PCSD is a rare type of primary parathyroid tumor with high malignancy and poor prognosis. Definitive diagnosis should be based on histopathological morphology and immunophenotype, and surgical treatment should be performed as soon as possible.
\end{abstract}

Keywords: Parathyroid carcinoma, Sacroma, Parathyroid, Case report, thyroid, sarcomatoid differentiation

\section{Background}

Parathyroid carcinoma(PC) is one of the rare cancers, accounting for less than $4 \%$ of cases of parathyroid diseases in the United States. DeQeurvain first described PC in 1904, which is characterized by high blood calcium and parathyroid hormone (PTH) levels [1]. However, PCSD is even rarer as a clinical solid tumor type. Nacamuli Randall first described this special type of parathyroid tumor in 2002 [2]. Since then, only four such cases have been reported including 2 cases abroad and 2 cases in China. The exact etiology of PC with sarcomatoid differentiation remains

\footnotetext{
* Correspondence: xxj701023@zju.edu.cn

Department of Thyroid Surgery, The First Affiliated Hospital, Zhejiang University School of Medicine, No. 79 Qingchun Road, Hangzhou 310003, PR China
}

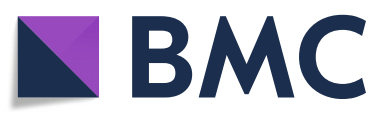

(c) The Author(s). 2020 Open Access This article is licensed under a Creative Commons Attribution 4.0 International License, which permits use, sharing, adaptation, distribution and reproduction in any medium or format, as long as you give appropriate credit to the original author(s) and the source, provide a link to the Creative Commons licence, and indicate if changes were made. The images or other third party material in this article are included in the article's Creative Commons licence, unless indicated otherwise in a credit line to the material. If material is not included in the article's Creative Commons licence and your intended use is not permitted by statutory regulation or exceeds the permitted use, you will need to obtain permission directly from the copyright holder. To view a copy of this licence, visit http://creativecommons.org/licenses/by/4.0/ The Creative Commons Public Domain Dedication waiver (http://creativecommons.org/publicdomain/zero/1.0/) applies to the data made available in this article, unless otherwise stated in a credit line to the data. unclear. Typical clinical manifestations may include hypercalcemia and high PTH level. It does not differ significantly from a general PC, but the tumor is more aggressive and has poor prognosis.

\section{Case presentation}

A 71-year-old male patient was admitted to hospital for hoarseness for $>1$ month. Ultrasound showed that the right thyroid was enlarged, bilateral thyroid nodules were present, the right larger nodules were about $4.5 \times 3.5 \mathrm{~cm}$, belonging to TI-RADS $4 \mathrm{a}$ type, and the left nodules belonged to TI-RADS 3 type (Fig. 1). Enhanced computed tomography (CT) showed a space-occupying lesion in the right thyroid area, invading the trachea and mediastinum (Fig. 2). 


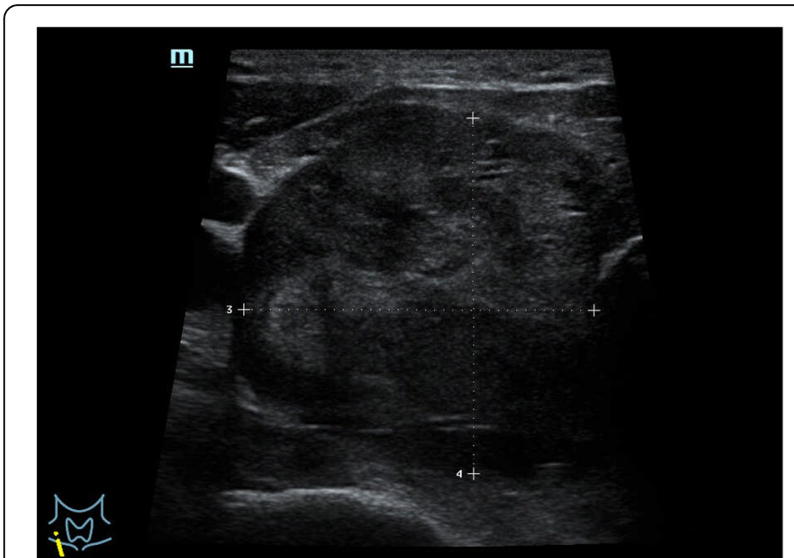

Fig. 1 Ultrasonography showed a right thyroid mass

Auxiliary examination showed that blood calcium was $2.34(2.0-2.69) \mathrm{mmol} / \mathrm{L}$, blood phosphorus 1.02 (0.87-1.45) $\mathrm{mmol} / \mathrm{L}$, PTH 89.1 (12.0-65.0) pg/ml, and tumor markers and other tests were all normal. Postoperative PTH was 40.9 (12.0-65.0) $\mathrm{pg} / \mathrm{ml}$, and serum calcium was $2.11(2.0-2.69) \mathrm{mmol} / \mathrm{L}$. Intraoperative exploration revealed a large mass of about $6 \mathrm{~cm}$ in the right thyroid area (Fig. 3), with unclear boundary, invading the esophagus and trachea,intraoperative frozen section pathology showed a malignant tumor with necrosis in the right thyroid area, which was confirmed by routine test and immunohistochemistry.
Postoperative pathology suggested a malignant tumor in the right thyroid area, combined with immunohistochemical results, which was consistent with carcinosarcoma composed of rhabdomyosarcoma, and this case was of parathyroid origin (Fig. 4). Immunohistochemical results were as follows: cytokeratin CK5/6 (-), P63 (-),thyroglobulin(TG) (-), PAX8 (-), CK7 $(-), \mathrm{CD} 30(-), \mathrm{Ki}-67(40 \%+++), \mathrm{Bcl}-2(-)$, cyclin D1 $(+)$, HMB $45(-)$, S-100 (-), melan A (-), transcription termination factor-1 (-), CK (Pan) (partial + ), smooth muscle actin (-), desmin (partial + ), MyoD1 (partial +$)$, myogenin (partial + ), epithelial membrane antigen (EMA) (partial +), CGA (partial +), Syn (partial + ), TFE3 $(-)$, GATA-3 $(+)$, p53 $(-)$ (Table 1 and Fig. 5). In this case, the capsule was thickened and parathyroid carcinoma cells were arranged in a diffuse sheet and trabecular manner. The tumor cells with clear cytoplasm and those with deviated eosinophilic nuclei were in a mixed, diffuse lamellar arrangement and central necrosis was seen. The tumor cells are large islands and sheets with foci of coagulative necrosis. Many cells with water-clear cytoplasm and sharp cell membrane, some of the cells are obviously eosinophilic, resembling rhabdomyoblasts, nuclei deviated, nucleoli are obvious, tumor cell nuclear division is not significant (Fig. 4d). The anaplastic thyroid carcinoma (undifferentiated carcinoma) usually has diverse morphology, obvious cell atypia, easy to see
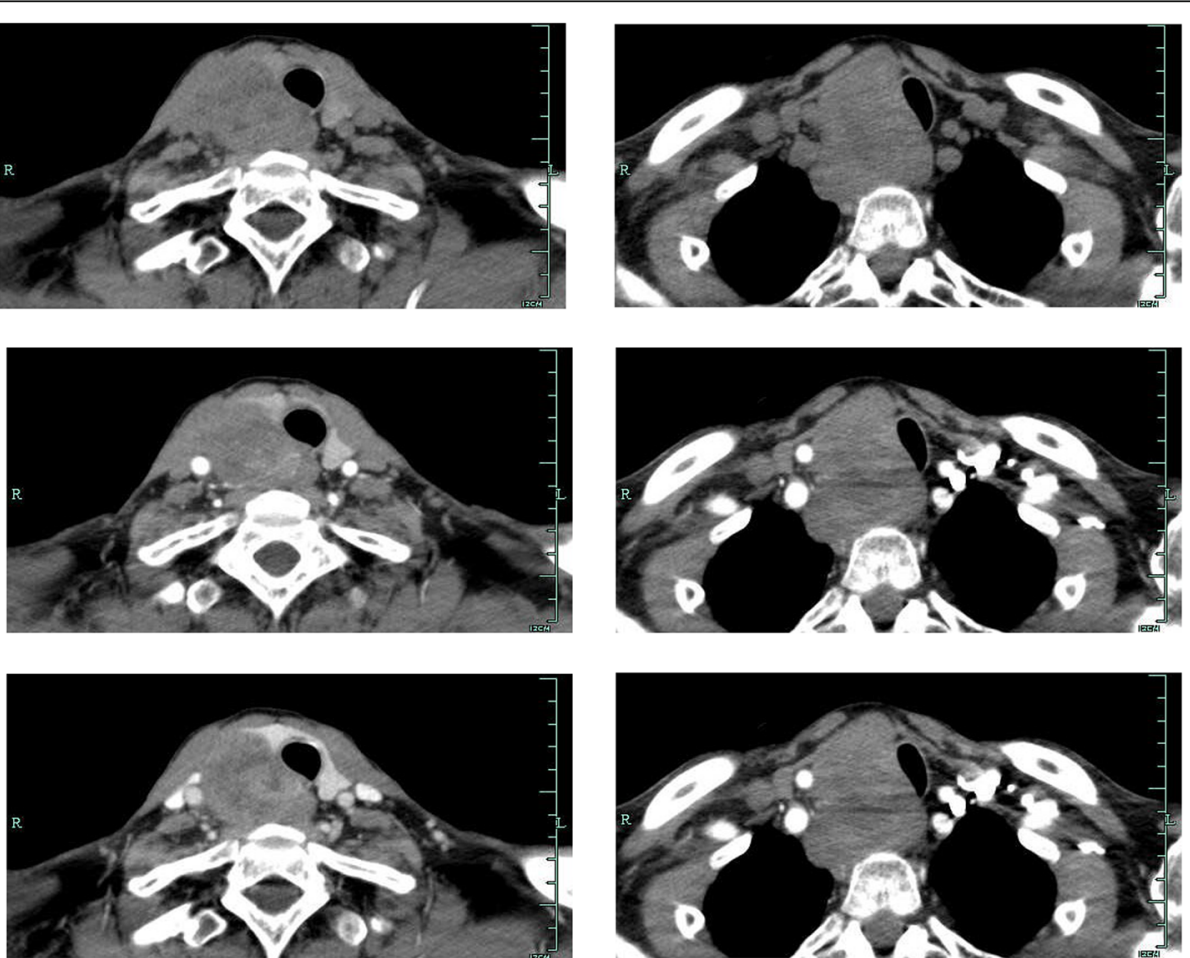

Fig. $2 \mathrm{CT}$ showed a large space-occupying lesion in the right thyroid region with invasion of the esophagus and mediastinum 


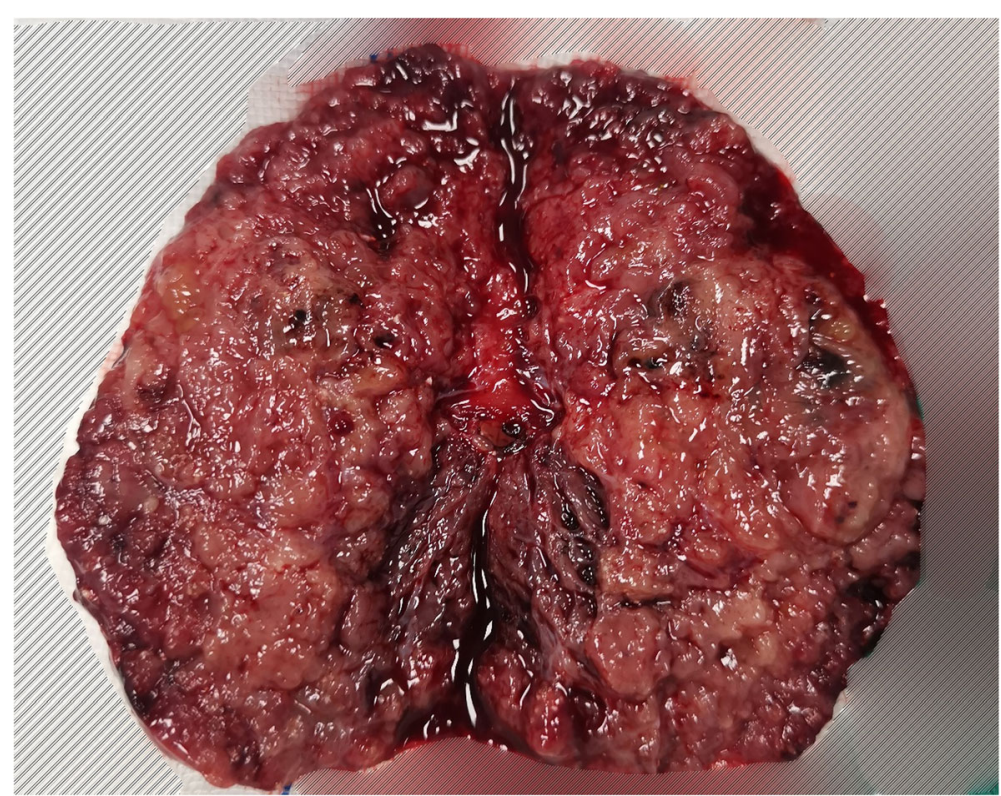

Fig. 3 Gross image of the case

mitotic images, immunohistochemical PAX8 positive (36-76\%), but this case has obvious clear cells, mitotic images are rare, PAX8 Negative, but GATA3 positive, which further proves that the tumor originates from the parathyroid gland. In addition to the classic microscopic features of $\mathrm{PC}$, there were rhabdomyoid tumor cells with eosinophilic cytoplasm, nuclear deviation and obvious nucleoli (Fig. 4). During the operation, invasion of peripheral organs, elevated $\mathrm{PTH}$, multiple positive immunohistochemical markers and genes were found, with rhabdomyosarcoma-like differentiation. After comprehensive consideration, Final diagnosis is parathyroid carcinoma with sarcomatoid differentiation(PCSD).

\section{Treatment and outcome}

This patient underwent palliative resection of the right neck mass. Because the tumor invaded the surrounding organs severely and could not be completely separated, palliative resection was performed. This patient refused any further treatment after surgery, and died 6 months after surgery.

\section{Discussion and conclusions}

$\mathrm{PC}$ is one of the rarest cancers. The 5-year survival rate of PC has been reported to be $78-85 \%$, and the 10 -year survival rate $49-77 \%$ [3-5]. It accounts for about $0.005 \%$ of all cancers [6]. The overall annual incidence rate is less than 1 case per million population $[7,8]$. The Surveillance, Epidemiology, and End Results (SEER) database showed that the incidence rate of parathyroid carcinoma was $3.6 / 10$ million in 2000-2012 [8]. The incidence rate of PC in Finland was 7.14/10 million from
2000 to 2013 [9]. According to Xing XP, a Chinese scholar, among patients with primary hyperparathyroidism (PHPT) confirmed by surgery and pathology, PC accounted for $3.10-10.53 \%$ [10], while PC accounted for $<1 \%$ of all PHPT patients in Europe and the United States, and 5\% in Japan $[11,12]$.

The exact pathogenesis of $\mathrm{PC}$ remains unclear. At present, most researchers believe that the occurrence of PC is new rather than transformed from adenoma, which is based on the inference that there are different gene changes between parathyroid adenoma and adenocarcinoma. The major genes reported are cdc73/HRPT2 [13-15], gcm2 [16, 17] and prune2 [18]. The detection rate of cdc73/HRPT2 gene mutation in sporadic PC is $46-70 \%[19,20]$. Nonaka et al. considered that $\mathrm{gcm} 2$ is the main regulatory gene of parathyroid development, and the marker is only expressed in the parathyroid gland, including normal parathyroid tissue and all forms of benign and malignant parathyroid lesions [16]. Additionally, abnormal expression of noncoding RNA including miRNA and long noncoding (lnc) RNA may also be involved in the development of PC [21]. In the future, lncRNA PVT1, GLIS2-AS1 and anti-Gcm2 antibodies may become markers for the diagnosis of PC [22].

The diagnosis of PCSD is generally based on the combination of histology, biology and radiology. Multidisciplinary cooperation is the best model. The diagnostic standard is as strict as for thyroid follicular carcinoma. Capsule invasion and/or vascular invasion, perineural space infiltration, tumor perforation into surrounding tissues and/or metastasis should be present. The main criteria for diagnosis are as follows: (1) the cancer cells are arranged in trabecular shape with thick fibrous 


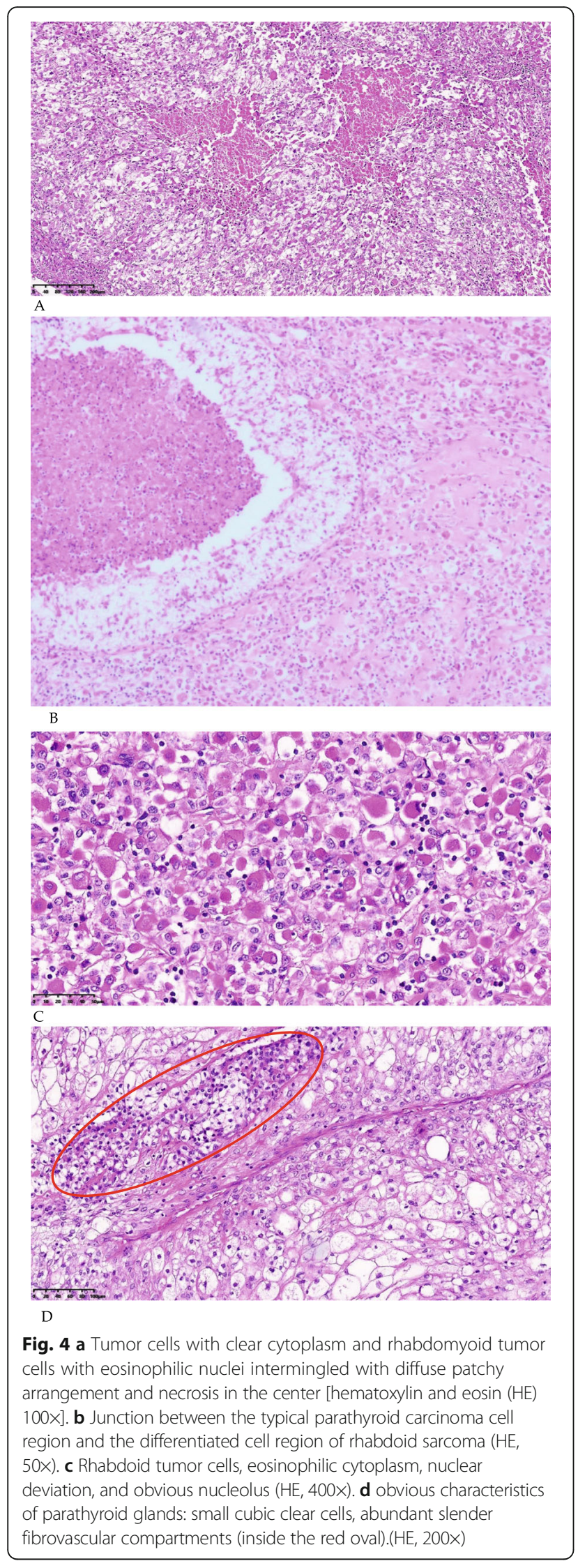

septum; (2) there is capsule or adjacent structure infiltration; (3) vascular invasion; (4) mitosis; (5) lymph node and/or other organ tissue metastasis; and (6) GATA3, cam5.2, SYN and CGA, which are important regulatory genes in parathyroid development, are positive. The loss of parafibromin and the high expression of PGP 9.5 and galectin-3 are helpful for the diagnosis of PC. At the same time, some tumor suppressor genes such as $\mathrm{Rb}$, APC, p27 and BCL2 are often not expressed or weakly expressed. When Ki-67 index is $>5 \%$, physicians should be alert to the possibility of malignant tumor [23].

Most PC patients have hypercalcemia, and about 3\% of them have no clinical symptoms [24]. The results of biochemical tests and the diameter of parathyroid lesions in PHPT patients can predict PC. In PHPT, the best cutoff point for predicting the diameter of parathyroid lesions in $\mathrm{PC}$ is $3.0 \mathrm{~cm}$ [25]. A retrospective analysis showed that preoperative ultrasound examination of parathyroid lesions $>15 \mathrm{~mm}$ was valuable in the diagnosis of PC [26]. PCSD is rare and only five cases (including our case) have been reported in the literature (Table 2).

Among these five cases, there were more women than men, and the tumor diameter was $>3.5 \mathrm{~cm}$, which was consistent with the report of Bae et al. The optimal cutoff point for predicting the diameter of parathyroid lesions was $3.0 \mathrm{~cm}$. The serum calcium level of most patients with PC was significantly higher than $3.5 \mathrm{mmol} / \mathrm{L}$. Serum PTH levels in patients with PC are usually 3-10 times higher than the upper limit of normal $[25,26]$. Elevated serum calcium and PTH are more common in patients with PCSD. Therefore, when the serum calcium level is $3 \mathrm{mmol} / \mathrm{L}$ and the parathyroid lesion is $>3 \mathrm{~cm}$ (i.e., the so-called $>3+>3$ rule) or ionic calcium $>1.77$ $\mathrm{mmol} / \mathrm{L}$, physicians should be fully vigilant about the possibility of PC [27].

Radical resection is the only way to cure PCSD. The first operation is particularly important and should be performed as soon as possible. During the first operation for $\mathrm{PC}$, parathyroid tumor with ipsilateral thyroid en bloc lobectomy including isthmus and ipsilateral central lymph node dissection should be performed [28-30]. If the tumor adheres to peripheral soft tissue, such as banded muscle and esophageal muscular layer, it should be removed as extensively as possible. If the recurrent laryngeal nerve is invaded, it should also be removed. Unfortunately, most of the PCSD have a high degree of malignancy. Most of them had distant metastasis in the early stage after surgery, and most of the patients died within 1 year after surgery.

Prophylactic lateral cervical lymph node dissection is generally not recommended because it does not prolong survival and may increase the incidence of 


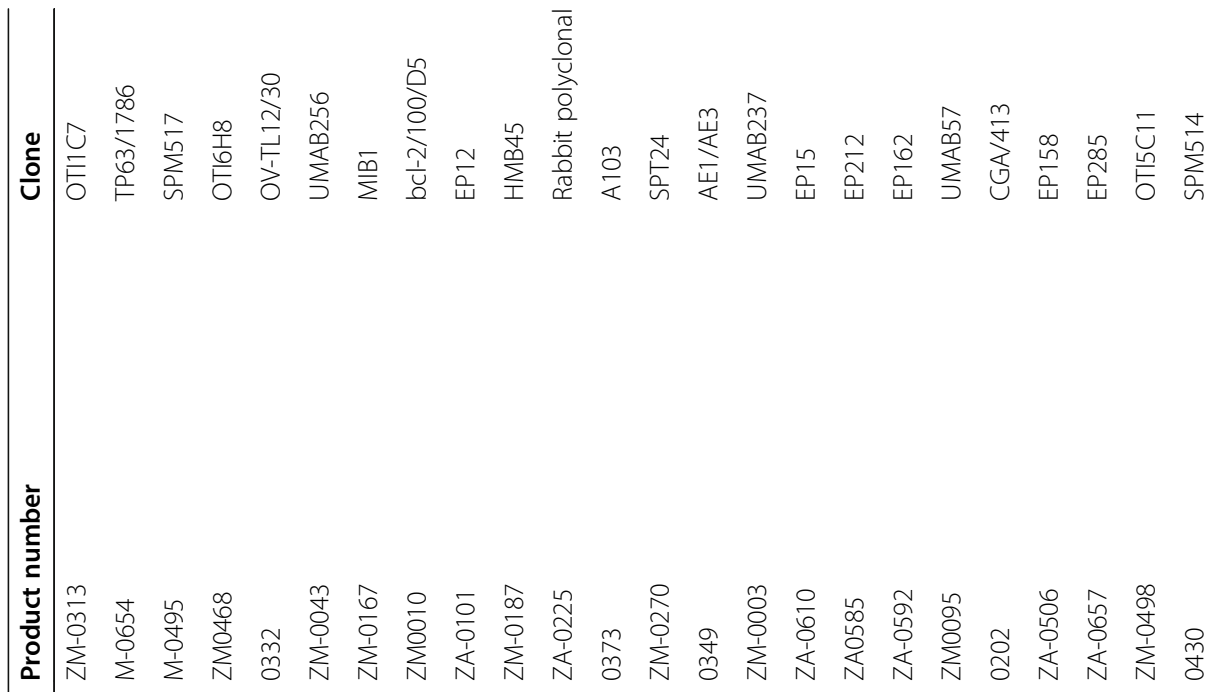

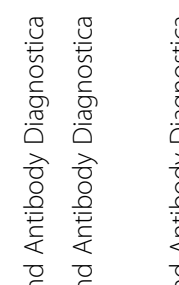
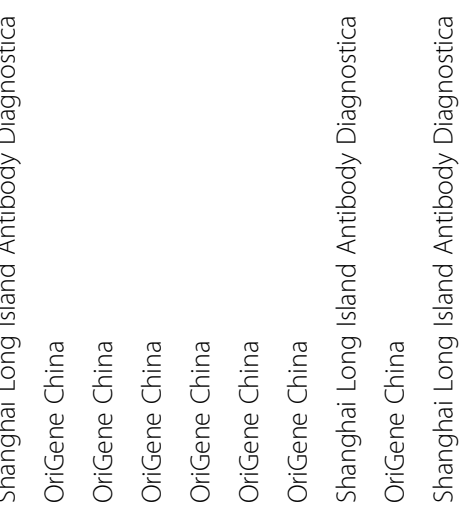

苛

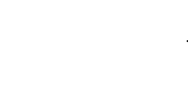

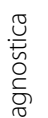




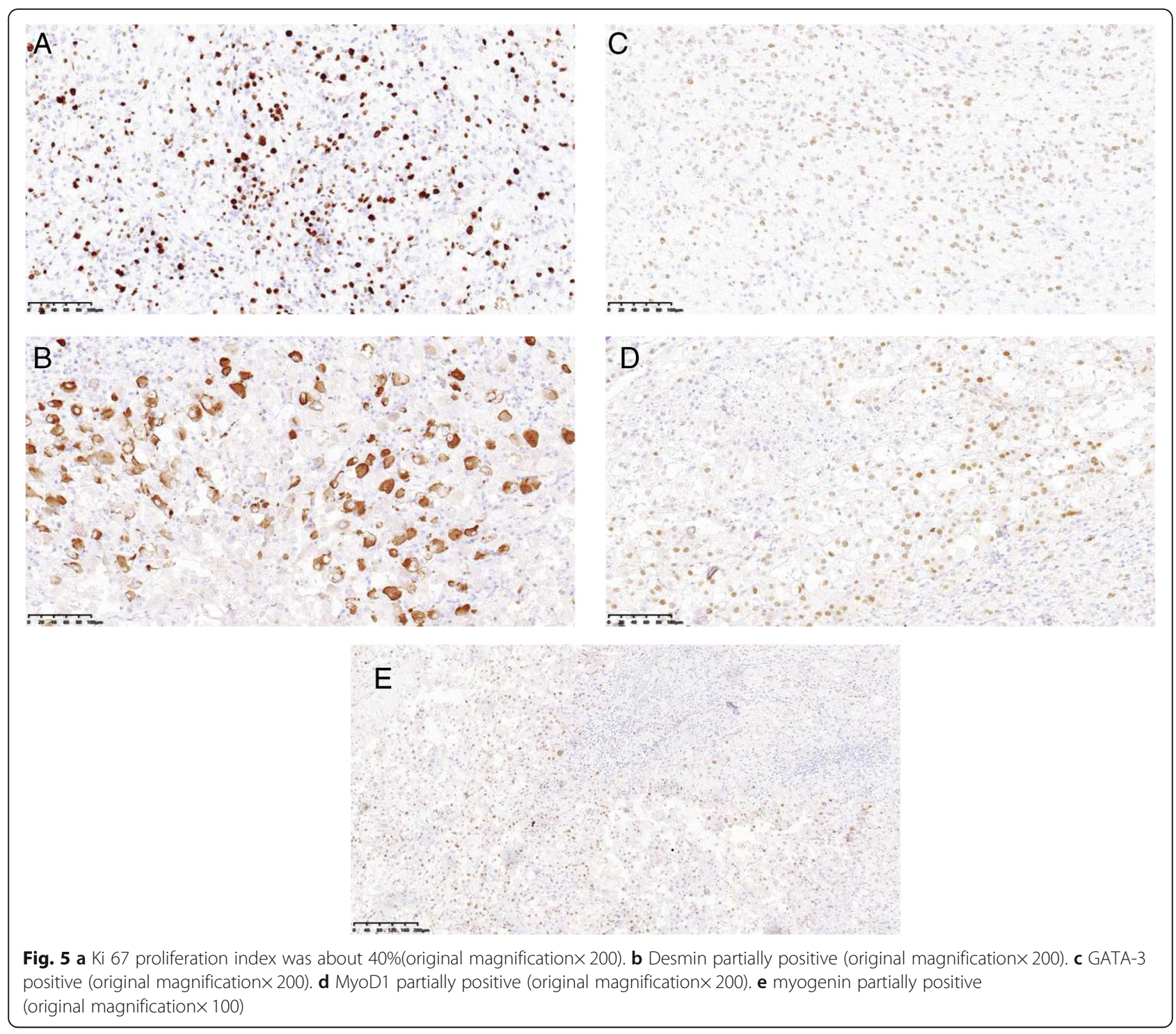

Table 2 Parathyroid carcinoma with sarcomatoid differentiation reported in the literature

\begin{tabular}{|c|c|c|c|c|c|c|c|}
\hline Authors & Sex & $\begin{array}{l}\text { Age } \\
\text { (yr) }\end{array}$ & $\begin{array}{l}\text { Maximum } \\
\text { diameter mass } \\
\text { (cm) }\end{array}$ & $\begin{array}{l}\text { Blood } \\
\text { calcium }\end{array}$ & Blood PTH & Positive Immunopheno type & Prognosis \\
\hline Taggart et al. & $\mathrm{F}$ & 57 & 4 & Normal & Normal & CGA and vimentin were positive & Lung metastasis \\
\hline Nacamuli et al. & M & 54 & 9 & Elevated & Elevated & $\begin{array}{l}\text { AE-1, PTH, CGA, Syn, and desmin } \\
\text { were positive }\end{array}$ & $\begin{array}{l}\text { Lung metastasis, adrenal } \\
\text { metastasis and death } 7 \text { mo } \\
\text { after surgery }\end{array}$ \\
\hline Zhang Haitao et al. & $\mathrm{F}$ & 57 & 7 & Elevated & Elevated & CK, Syn, PTH, Ki-67 was 50\% & Unclear \\
\hline Guan Zhongyan et al. & $\mathrm{F}$ & 62 & 3.5 & Normal & Undetermined & $\begin{array}{l}\text { CK8/18, CGA, CD56, galectin-3 } \\
\text { and vimentin were positive }\end{array}$ & $\begin{array}{l}\text { Lung metastasis, and death } \\
5 \text { months after surgery }\end{array}$ \\
\hline Present case & M & 71 & 4.5 & Normal & Elevated & $\begin{array}{l}\text { Desmin, MyoD1, Myogenin, EMA, } \\
\text { CGA, Syn, CK, GATA-3 were positive, } \\
\text { Ki-67 was } 40 \%\end{array}$ & $\begin{array}{l}\text { Esophageal and mediastinal } \\
\text { invasion and death } 6 \text { mo after } \\
\text { surgery }\end{array}$ \\
\hline
\end{tabular}


complications. However, if lateral cervical lymph node metastasis is confirmed before surgery, therapeutic dissection is required. The biggest difficulty in the selection of surgical methods is the low accuracy of intraoperative frozen pathological diagnosis of PCSD. Unless there is obvious capsule, vascular invasion or regional lymph node metastasis, there are generally few direct reports of parathyroid cancer. When PCSD is diagnosed by parathyroid pathology after surgery, it is advisable to supplement surgery in time according to parathyroid cancer.

Chemotherapy drugs are generally ineffective against PCSD [31], and there are only a few successful reports [32]. PCSD is not sensitive to radiotherapy. Although there are reports of adjuvant radiotherapy to reduce local recurrence after the initial operation [33], due to the small number of cases and short follow-up time, adjuvant radiotherapy may only be used in PCSD patients with high risk of recurrence [34]. For local lesions, such as lung metastasis and vertebral metastasis, there are also individual cases of attempting radiofrequency ablation or absolute alcohol or combined percutaneous vertebroplasty to destroy metastases [35].

PCSD is a rare type of primary parathyroid tumor with high malignancy and poor prognosis. Definitive diagnosis should be based on histopathological morphology and immunophenotype, and surgical treatment should be performed as soon as possible.

\section{Abbreviations \\ PC: Parathyroid carcinoma; PCSD: Parathyroid carcinoma with sarcomatoid differentiation; PTH: Parathyroid hormone; CT: Computed tomography; PHPT: Primary hyperparathyroidism; CGA: Chromogranin A; \\ Syn: Synaptophysin; TG: Thyroglobulin; MyoD1: Myogenic differentiation 1}

\author{
Acknowledgements \\ The authors would like to thank our patient for allowing for his case to be \\ presented.
}

Informed consent statement

Informed consent was obtained from the patient.

\section{Written informed consent}

Patient has provided informed consent for publication of the case.

\section{Conflict-of-interest statement}

The authors declare that there is no conflict of interest related to this report.

\section{Ethical statement}

Written informed consent was obtained from the patient. Ethical approval was obtained from the Ethics Committee of the First Affiliated Hospital, School of Medicine,Zhejiang University, China, in accordance with the ethical guidelines of the 1975 Declaration of Helsinki.

\section{Authors' contributions}

Conceptualization: Liang Hu and Xiaojun Xie. Supervision: Liang Hu and Xiaojun Xie. Writing - original draft: Liang Hu. Writing - review \& editing: Xiaojun Xie. The author(s) read and approved the final manuscript.

\section{Funding}

Not applicable.

\section{Availability of data and materials}

All data generated or analysed during this study are included in this published article.

\section{Ethics approval and consent to participate}

Written informed consent was obtained from all participants. Ethical approval was obtained from the Ethics Committee of the First Affiliated Hospital, School of Medicine, Zhejiang University, China, in accordance with the ethical guidelines of the 1975 Declaration of Helsinki. Written informed consent was obtained from the patient for publication of this case report and any accompanying images. A copy of the written consent is available for review by the Editor in-Chief of this journal.

\section{Consent for publication}

Written informed consent for publication was obtained from all participants.

\section{Competing interests}

The authors declare that they have no competing interests.

Received: 8 September 2020 Accepted: 6 December 2020

Published online: 14 December 2020

\section{References}

1. Carlson D. Parathyroid pathology: hyperparathyroidism and parathyroid tumors. Arch Pathol Lab Med. 2010;134(11):1639-44.

2. Nacamuli R, Rumore GJ, Clark G. Parathyroid carcinosarcoma: a previously unreported entity. Am Surg. 2002;68(10):900-3.

3. Avital H, Avantika W, Gustavo FR, Jimmy H, Insoo S, Elliot M, et al. Parathyroid carcinoma: a 43-year outcome and survival analysis. J Clin Endocrinol Metab. 2011;12:3679-86.

4. Sherman $\mathrm{Sl}$, Diaz EM Jr, Asper JA, Hoff AO, Wirfel K, Busaidy NL, et al. Parathyroid carcinoma: A 22-year experience. Head Neck. 2004;26(8):716-26.

5. Hundahl SA, Fleming ID, Fremgen AM, Menck HR. Two hundred eighty-six cases of parathyroid carcinoma treated in the U.S. between 1985-1995: a National Cancer Data Base Report. The American College of Surgeons Commission on Cancer and the American Cancer Society. Cancer. 1999; 86(3):538-44.

6. Cetani F, Pardi E, Marcocci C. Parathyroid carcinoma: a clinical and genetic perspective. Minerva Endocrinol. 2018:43(2):144-55.

7. Lee PK, Jarosek SL, Virnig BA, Evasovich M, Tuttle TM. Trends in the incidence and treatment of parathyroid cancer in the United States. Cancer. 2010;109(9):1736-41.

8. Benjamin CJ, Briseis, et al. The Incidence and Survival of Rare Cancers of the Thyroid, Parathyroid, Adrenal, and Pancreas. Ann Surg Oncol. 2016;23(2): 424-33.

9. Ryh Nen EM, Leijon H, Metso S, Eloranta E, Korsoff P, Ahtiainen P, et al. A nationwide study on parathyroid carcinoma. Acta Oncol. 2017;56(7): 991-1003.

10. Xiaoping X, Ou W, Xunwu M, Weibo X, Mei L, Yan J, et al. Comparison of clinical manifestations in patients with primary hyperparathyroidism between districts of Beijing and New York. J Diagn Concepts Pract. 2006; 5(006):483-6.

11. Delellis R. Pathology and genetics. Tumours of endocrine organs. World Health Organization Classification of Tumours; 2004.

12. Delellis RA, Mangray S. Heritable forms of primary hyperparathyroidism: a current perspective. Histopathology. 2018;72(1):117-32.

13. Shattuck TM, Vlimki S, Obara T, Gaz RD, Arnold A. Somatic and germ-line mutations of the HRPT2 gene in sporadic parathyroid carcinoma. N Engl J Med. 2003;349(18):1722.

14. Chiara V, Sabrina C. Epigenetic Alterations in Parathyroid Cancers. Int J Mol Sci. 2017;18(2):310

15. Guarnieri V, Muscarella LA, Verdelli C, Corbetta S. Alterations of DNA methylation in parathyroid tumors. Mol Cell Endocrinol. 2018;469:60-9.

16. Nonaka D. Study of parathyroid transcription factor $\mathrm{Gcm} 2$ expression in parathyroid lesions. Am J Surg Pathol. 2011;35(1):145-51.

17. El Lakis M, Nockel P, Guan B, Agarwal S, Welch J, Simonds WF, et al. Familial isolated primary hyperparathyroidism associated with germline GCM2 mutations is more aggressive and has lesser rate of biochemical cure. Surgery. 2018;163(1):31-4.

18. Yu W, McPherson JR, Mark S, Ve R, Lee HH, Paul N, et al. Whole-exome sequencing studies of parathyroid carcinomas reveal novel PRUNE2 
mutations, distinctive mutational spectra related to APOBEC-catalyzed DNA mutagenesis and mutational enrichment in kinases associated with cell migration and invasion. J Clin Endocrinol Metab. 2015;100(2):E360-4..

19. Ou W, Chunyan W, Min N, Quancai C, Heng G, Yan J, et al. Novel HRPT2/ CDC73 gene mutations and loss of expression of Parafibromin in Chinese patients with clinically sporadic parathyroid carcinomas. PLoS One. 2012; 7(9):e45567.

20. Cetani F, Pardi E, Marcocci C. Update on parathyroid carcinoma. J Endocrinol Investig. 2016;39(6):595-606.

21. Hu Y, Zhang $X$, Cui M, Su Z, Wang M, Liao $Q$, et al. Verification of candidate microRNA markers for parathyroid carcinoma. Endocrine. 2018;60(2):246-54.

22. Xiang Z, Ya H, Mengyi W, et al. Profiling analysis of long non-coding RNA and mRNA in parathyroid carcinoma. Endocr Relat Cancer. 2019; 26(2):163-76.

23. Erickson LA, Mete O. Immunohistochemistry in diagnostic parathyroid pathology. Endocr Pathol. 2018;29(2):113-29.

24. Okamoto T, lihara M, Obara T, Tsukada T. Parathyroid carcinoma: etiology, diagnosis, and treatment. World J Surg. 2009;33(11):2343-54.

25. Hyun BJ, Jin CH, Yenna L, Kyong MM, Joo PY, Soo SC, et al. Preoperative predictive factors for parathyroid carcinoma in patients with primary hyperparathyroidism. J Korean Med Sci. 2012;27(8):890-5.

26. Sidhu PS, Talat N, Patel P, Mulholland NJ, Schulte KM. Ultrasound features of malignancy in the preoperative diagnosis of parathyroid cancer: a retrospective analysis of parathyroid tumours larger than $15 \mathrm{~mm}$. Eur Radiol. 2011;21(9):1865-73.

27. Antonio S, Salcuni F, Cetani V, et al. Parathyroid carcinoma. Best Pract Res Clin Endocrinol Metab. 2019;51:63-76.

28. Do Cao C, Aubert S, Trinel C, Odou MFO, Bayaram M, Patey M. Parathyroid carcinoma: Diagnostic criteria, classification, evaluation. Annales Dendocrinologie. 2015;76(2):165-8.

29. Schantz A, Castleman B. Parathyroid carcinoma. A study of 70 cases. Cancer 1973;31(3):600-5.

30. Bondeson L, Sandelin K, Grimelius L. Histopathological variables and DNA cytometry in parathyroid carcinoma. Am J Surg Pathol. 1993;17(8):820-9.

31. Tsoli M, Angelousi A, Rontogianni D, Stratakis C, Kaltsas G. Atypical manifestation of parathyroid carcinoma with late-onset distant metastases. Endocrinol Diabetes Metab Case Rep. 2017:2017(1):17-0106.

32. Marcocci C, Cetani F, Bilezikian JP. Parathyroid carcinoma. J Bone Miner Res. 2010;23(12):1869-80

33. Clayman GL, Gonzalez HE, El-Naggar A, Vassilopoulou-Sellin R. Parathyroid carcinoma: evaluation and interdisciplinary management. Cancer. 2010; 100(5):900-5.

34. Fyfe ST, Hoover LA, Zuckerbraun L, David GM. Parathyroid carcinoma: clinical presentation and treatment. Am J Otolaryngol. 1990;11(4):268-73.

35. Zhong-ling Q, Chun-gen W, Rui-sen Z, Yan-li X, Quan-yong L. Unusual case of solitary functioning bone metastasis from a "parathyroid adenoma": Imagiologic diagnosis and treatment with percutaneous Vertebroplasty - case report and literature review. J Clin Endocrinol Metab. 2013;98(9):3555-61.

\section{Publisher's Note}

Springer Nature remains neutral with regard to jurisdictional claims in published maps and institutional affiliations.

Ready to submit your research? Choose BMC and benefit from:

- fast, convenient online submission

- thorough peer review by experienced researchers in your field

- rapid publication on acceptance

- support for research data, including large and complex data types

- gold Open Access which fosters wider collaboration and increased citations

- maximum visibility for your research: over $100 \mathrm{M}$ website views per year

At BMC, research is always in progress.

Learn more biomedcentral.com/submissions 